\title{
Race, Class, and Money in Disaster
}

\author{
Naomi Zack \\ University of Oregon
}

\section{Shame}

We are a society that treats human remains with respect. In wartime, the dead are transported home and buried with great solemnity, attended by their friends, relatives, neighbors, and public dignitaries. The flags that drape their coffins are ceremoniously folded and reverently handed to spouses, parents, or children. In the days after the World Trade Center collapsed, New York City Fire Department personnel worked around the clock, forming brigades to carefully bring out containers of human remains. During the fire fight at the Pentagon, the FBI meticulously oversaw the search for, and retrieval, documentation, and transportation of, human remains. The remains ranged in size from tissue measured in inches to intact corpses. Each set of remains was carried out of the Pentagon by at least two members the Old Guard elite ceremonial unit from Fort Myers, who were escorted in and out of the Pentagon for that purpose by FEMA officials. Great care was taken to avoid media and Internet spectacles of "body parts." Official efforts of this nature are intended to protect human dignity, as well as to honor those who died while serving their country.

For days after Hurricane Katrina, the world continually viewed Ethel Freeman's body in her wheelchair at the Superdome. Corpses floating face down in floodwater or left to bloat on the streets of New Orleans were repeatedly visible on hundreds of millions of computer and television screens. These images and what they depicted were violations of human dignity.

In Bob Dylan's 1964 protest song, "The Lonesome Death of Hattie Carroll," there is a refrain to "You who philosophize disgrace and criticize all fears," which cautions as the story unfolds, "Now ain't the time for your tears." The song is based on a true story. William Zantzinger (the ' $t$ ' is left out of his name in the song), a twenty-four-year-old son of white Southern land owners, killed Hattie Carroll, fifty years old and black, a hotel kitchen worker and mother of ten, by slinging his cane at her across a room. Zantzinger was arrested, released on bail, 
convicted by an all-white jury, and then sentenced by the judge. ${ }^{3}$ After Dylan recounts that Zantzinger got a sentence of six months, he ends, "Now's the time for your tears."

The overt, violent racism that Dylan and others exposed for public view during the civil rights movements is no longer morally acceptable in its communities of origin. But terrible violations of human dignity continue to happen to black people in the United States, in normal life, as well as in disaster. These affronts, and the pain and grief they cause, are ameliorated, but not expunged, by the fact that most whites would not now deliberately inflict them or tolerate those who do. When blacks, but not whites, suffer such affronts, the general evil of widespread intentional racism in the past is evoked.

In every civilian disaster thus far, the already-disadvantaged have suffered most, and there is little doubt that this will continue to happen. Legal and political arguments for preventing that continuity are not likely to be immediately effective. Neither moral argument nor cultural criticism is decisive, but both are worth developing because they reframe ideals and encourage public debate. At the least, they may spur gratuitous compassionate responses from authorities, which although arbitrary, do save lives and preserve dignity. After Hurricane Katrina, President Bush signed the bill requiring states to provide for pet safety in disasters $;{ }^{4}$ during the wildfires in Southern California in October 2007, official action against illegal immigration was reported to be partly curtailed, and there appeared to be adequate emergency facilities for evacuees with proof of citizenship or legal residence who could not afford hotels; ${ }^{5}$ President Bush directed the FAA and exhorted the airlines to minimize delays during the 2007 holiday season, and the airlines pledged compliance. ${ }^{6}$ These are all only gestures, compared to what was not done during Hurricane Katrina, but they reveal an ongoing concern for the appearance of compassion and benevolence, which reinforces compassion and benevolence as public virtues.

Anthropologists and social critics distinguish between shame cultures and guilt cultures. Shame cultures have dominant groups with stringent codes of honor and decorum, and individual moral status depends on the opinion of high-status peers. Guilt cultures are less hierarchical and their focus on individual responsibility and conscience allows for greater independence of moral status from the views of others. Homeric Greece is famously a shame culture, whereas the Christian-Judaic tradition has produced guilt cultures. To the extent that it views itself as a Christian, individualistic, classless society, the United States is a guilt culture. But to the extent that what is said and done by the rich, powerful, and famous, particularly politicians, is immediately publicized by the media, we are a shame culture.

Ordinary white people who hold racists views and treat people of color aversively, or disrespectfully, are not usually punished, 
apart from the negative judgments by some of those who know them. But elected and appointed political figures, top executives of major corporations, and celebrities cannot make racist remarks or be perceived as racist without incurring very bad press or losing their jobs. It is now shameful for the elite to be known as racist. The intelligentsia usually keeps its collective moral eye on the behavior of the rich and powerful, with the help of the media. And one way in which the media does guard democracy is by the use and threat of scandal.

However, this system of moral vigilance, which can achieve social justice by means of public shame, is inherently arbitrary. Shame cultures are only as moral as the standard to which the elite are held. American mores change from one decade to the next and any sensational story may be eclipsed by a bigger one. The media and public do a poor job of distinguishing between the importance of private moral misdeeds and immoral actions that substantially affect human welfare. (Sexual misconduct can receive as much attention as economic or political betrayals of public trust.) Still, as the public's intolerance of racism displayed by the elite shows, some of the worst forms of contemporary public shame involve injuries to the dignity of others. However, while this preserves general standards of human dignity, the victims of insult, abuse, or neglect, which it was shameful for others to inflict on them, are inevitably shamed as well.

\section{Social Inequality and Disaster}

The pragmatics of shame is limited. Public figures and others of status can be shamed for specific deeds, but there is no mechanism to shame them for the long-term benefits that derive from the misfortunes of others, because they so often mistake their status for their personal character. What they own is fully theirs, according to their right to private property: If they have made their own fortune, they deserve it, regardless of who suffered in the process; If they have inherited what they own, then their status is even higher, because their money is "older," no matter how their ancestors acquired wealth. Although the strategic uses of shame cannot be overlooked, when moral conscience is lax (i.e., when there are no promptings by conscience and no feelings of guilt after misbehavior), principled cultural criticism, based on enduring ideals, remains important. It would be more principled than the uses of shame and guilt and would probably lead to more sound changes in institutional structures, if racism in disaster were effectively addressed, first, as moral cultural criticism, second, as legal argument, and third, as changes in laws and policies.

If the factor of nonwhite race is held constant in American society, there is great socioeconomic diversity within each racial 
group, and class does not neatly line up with race. For example, there are affluent blacks who live better than many whites. But if social class is held constant, then within each income group, blacks and other minorities fare worse than whites in education, employment status, criminal incarceration, and overall health. In the United States, the most disadvantaged groups are constituted by combinations of nonwhite race and poverty. The lack of disaster preparation by, and for, the most disadvantaged in itself further disadvantages them. Lost wages may result in homelessness for renters. In other parts of the world, the most disadvantaged intersections may be the result of ethnicity, nationality, or religion, and class, but the principle is the same: Disaster magnifies social inequality.

Middle-class people who survive disasters without prior preparation can recover their predisaster lives and assets with work and effort. The rich fare even better. Naomi Klein notes that Help Jet, an airline in West Palm Beach, Florida, advertises as "the first hurricane escape plan that turns a hurricane evacuation into a jet-setter vacation:

Upon storm warnings, reservations are made for passengers at five-star golf resorts, spas, or Disneyland. Evacuees leave the hurricane zone on a thirty passenger turboprop: "No standing in lines, no hassle with crowds, just a first class experience that turns a problem into a vacation.... Enjoy the feeling of avoiding the usual hurricane evacuation nightmare."

Passengers can bring their pets. ${ }^{8}$ Membership is $\$ 500$ a year and round-trip airfare was about $\$ 2,000$ in the 2006 hurricane season. (Talk about "white flight"!)

The average human for disaster survival is often imagined to be an able-bodied, young or middle-aged white male. He is the likely hero and survivor, the norm for a traditional majority of the American population, and he is in fact the norm from the perspective of emergency workers and the military, even though both institutions are increasingly diverse in race and gender. In civilian disasters, women, children, the elderly, the poor, recent immigrants, the disabled, and racial minorities have prior disadvantages compared to this norm, some self-evident in terms of physical capabilities and stamina, some more subtle in being objects of social bias. The ideal of egalitarian disaster assistance would be for those assisting to have enough supplies and personnel available to be speedily dispatched, so as to dispense goods and services fairly, to meet everyone's needs. Many think that this is exactly what did not happen after Hurricane Katrina. (Studies of what went wrong in New Orleans will probably ground the careers of a generation of academics and practitioners-unless/until there is a worse event.) 


\section{Hurricane Katrina}

The undisputed facts (as of this writing in November 2007) are as follows. Hurricane Katrina was the most destructive natural disaster in American history, surpassing the Chicago Fire of 1871, the San Francisco Earthquake and Fire of 1906, and Hurricane Andrew in 1992. Over one hundred billion dollars of damage resulted. The damage extended 103 miles from Katrina's center, covering 93,000 square miles, and 138 parishes and counties. Levees were overwhelmed on the lowest parts of the Mississippi River and Lake Pontchartrain. Three canals flooded in New Orleans, affecting 80 percent of the city. An estimated 300,000 homes were destroyed or left uninhabitable. There was additional destruction to commercial buildings, forests, and green spaces, with debris of 118 million cubic yards (over ten miles high if stacked on a football field).

After Katrina, the unemployment rate doubled from 6 to 12 percent in the hardest hit parts of Louisiana and Mississippi. One-fifth of the yearly output of oil production in the Gulf of Mexico was unused due to Hurricane Katrina and also Hurricane Rita that struck on the border between Louisiana and Texas on September 24, 2005. There was spillage of 7.4 million gallons of oil into Gulf Coast waterways. In addition to environmental damage and pollution from standing water, sewage, chemicals, and human and animal remains, there was damage to $466 \mathrm{chem}-$ ical facilities, 31 hazardous waste sites, 16 Superfund toxic waste sites, 170 drinking water facilities, and dozens of wastewater treatment facilities.

Estimates of Katrina deaths over the region range from 1300 to 1500 . About 80 percent of these deaths were in New Orleans. In Louisiana, 51 percent of those who died were older than sixty, and 47 percent were older than seventy-five. By February 2006, two hundred bodies were unclaimed at the Victim Identification Center in Carville, Louisiana, and over 2,000 people were still reported missing. Three-quarters of a million people were displaced, many without vital documents, medical records, or insurance information. In August 2005, 1.1 million people over age sixteen evacuated, and approximately $267,000,80$ percent of whom were black, had not returned by fall $2007.9^{9}$

Governor Kathleen Blanco of Louisiana declared a state of emergency on Friday, August 26, 2005. In response to her request, on August 27, President Bush declared a federal state of emergency for Louisiana and gave FEMA authority to mobilize whatever rescue efforts were needed. Also, on the evening of August 27, Governor Blanco made a personal plea to President Bush on behalf of storm victims in Louisiana, for "everything you've got." On August 28, Katrina was upgraded to a category 5 storm and the National Weather Service warned that power outages would last for weeks and "water shortages will make 
human suffering incredible by modern standards." Mayor Ray Nagin of New Orleans ordered an evacuation of the city. Michael Brown, Director of FEMA, and President Bush were briefed by Max Mayfield, Director of the National Hurricane Center, and told that the levees could be "topped." Katrina made landfall at 7 a.m. on Monday, August 29, as a Category 4 hurricane. That morning, Mayor Nagin reported on the "Today Show" that water was coming over levees. Brown only asked Michael Chertoff, Secretary of FEMA, for 1,000 Homeland Security employees to be dispatched to the Gulf Coast, five hours after the storm hit. It then took the FEMA personnel two days to get to New Orleans. President Bush flew over the region on Friday, September 2, the fifth day, and expressed sympathy for Mississippi Senator Trent Lott's loss of his house.

Louisiana is the second poorest state in the United States. The residents of New Orleans were 63 percent black, half with incomes below the poverty line. Almost 60 percent of the poor black households in New Orleans lacked a vehicle, so many could not leave the city when the evacuation was ordered the day before the storm. After Katrina made landfall, it took five days for significant aid to arrive and the only official assistance from city government was advice that those flooded out of their homes get to the Superdome, to wait for buses out of the city. ${ }^{10}$

Multigenerational poverty in America makes people more vulnerable in disasters. All over the world, the poor are less physically mobile than those with more money. This is partly due to obvious economics, for example, no cars in the Katrina case, and partly because the poor often have close familial and neighborhood ties in one specific place. New Orleans was not just any place, but one of the richest cultural and historical cities in the United States. It could easily have been predicted that many of the poor in New Orleans would not be willing or able to follow a general order to evacuate, and that relocation would represent deep cultural and personal hardships for them. ${ }^{11}$

After FEMA's initial assistance, which was extended several times, there was no government policy to support a return home for the poor who wanted to come back. On the contrary, there is evidence that the post-Katrina power structure in New Orleans immediately had a vision for development that would exclude the relocated black poor. Julian Bond notes that, soon after the storm, in a meeting between Mayor Nagin and the Urban Land Institute, an organization of corporate land developers, there was a proposal of "forced mass buyouts of low-lying neighborhoods, including the Ninth Ward, for conversion into "green corridors." Bond also quotes a study of the Center for Social Inclusion:

The unfortunate truth is, in evaluating the ability of New Orleans' residents to return,... under current policies and fundings, few communities can be expected to recover. Most of those who have 
returned, or will be able to return or relocate to the New Orleans Metropolitan region, will be white and relatively well-off. ${ }^{12}$

\section{Institutional Genocide?}

One may still wonder, as many have already, how it was possible for 100,000 Americans to be so abused and neglected at the same time. The large number might provide a clue. Americans pride themselves on egalitarianism in the treatment of individuals, and all of the nondiscrimination language in founding documents, constitutional amendments, and the civil rights and immigration reform legislation of the $1960 \mathrm{~s}$, refers to what may not be done to individuals. Historically, bigots and racists who have held the worst beliefs about minorities have often made exceptions for a few individuals. The worst beliefs, which is to say, the most malign and humanly degrading myths and stereotypes, are reserved for the majorities of despised groups.

The images and rumors of crimes committed by black Katrina victims were an integral part of delayed rescue efforts. In "Disasters, Race and Disability," Lakshmi Fjord notes that in the U.S. House of Representatives' Katrina Report, there was criticism of the administration's reliance for information on media reports, rather than on satellite images or communication with on-site experts. ${ }^{13}$ Alongside the tragic pictures of stranded evacuees and people stuck on rooftops, there were pictures and reports of "looting" by blacks, which have been contrasted with depictions of whites doing the same thing, but under noncriminal descriptions (e.g., "finding food" versus "stealing"). The media also reported rumors of snipers firing on rescue helicopters, a seven-year-old rape victim whose throat had been slit, and thirty or forty dead bodies stacked in the Convention Center freezer. The U.S. House of Representatives' Report laid to rest as false the rumors of the snipers, rape, and stacked dead bodies, but only after a year had passed. When the rumors were circulating, the National Guard entered the city with guns in position, ready to "pacify" the mass, so that it could be rescued.

The reports of rampant lawlessness, especially the persistent urban legend of shooting at helicopters definitely delayed some emergency and law enforcement responses. The National Guard refused to approach the Convention Center until September 2, 100 hours after the hurricane because "we waited until we had enough force in place to do an overwhelming force," Lieutenant General H. Steven Blum, Chief of the National Guard Bureau told reporters on September 5, 2005. (The Katrina Report 2006, 170) ${ }^{14}$

But,

One of my good friends, Col. Jacques Thibodeau, led that security effort. They said, 'Jacques, you gotta get down here and sweep this 
thing'. He says he was braced for anything. And he encountered nothing-other than a whole lot of people clapping and cheering and so glad they were there. (Major Ed Bush, The Katrina Report $2006,171)^{15}$

From the perspective of FEMA, the President, and the viewing public, including African Americans (for example Secretary of State Condoleezza Rice, who was reported "out on the town," in New York City, buying shoes, dining, watching a Broadway show ${ }^{16}$ ), everything necessary was being done in those first 100 hours. On the Friday he visited New Orleans (the fifth day), George Bush said to Michael Brown, Director of FEMA, "Brownie, you're doing a heckuva job."17

Of course, we now know, and will continue to learn for many years, how the reality was different from the initial accounts based on stereotypes. The reality traumatized victims, as it betrayed their trust. Can anyone who has not experienced what Clarice Butler, a nurses' assistant for twenty-eight years, experienced on the interstate in New Orleans, dismiss the following as a paranoid utterance?

They tried to kill us. When you keep people on top of the interstate for five days, with no food and water, that's killing people.... Helicopters at night shining a light down on us. They know we was there. Policemen, the army, the whole nine yards, ambulance passing us up like we wasn't nothing.... We was treated worse than an animal. ${ }^{18}$

Stereotypes of a large group of people can fuel the plot of a "script" for what is believed likely to happen. When the group is stereotyped as incompetent and criminal, observers may expect the group to perish. ${ }^{19}$ If those observers are also a source of assistance, such a belief can become a self-fulfilling prophecy. People are less inclined to help those who are incompetent and criminal, than the able and innocent. In that sense, There is not safety, but danger in numbers. What happened in New Orleans after Hurricane Katrina was not exactly genocide or attempted genocide, because the survival of the whole population of African Americans was not at stake and there is no evidence of intention to kill the whole group or even all members residing in New Orleans. But 100,000 is a large number by anyone's standards, there was life-threatening neglect, and the victims were already socially despised in accord with current negative stereotypes of "inner city poor."

The concept of institutional racism has been a staple of critical race discourse since the 1960 s. ${ }^{20}$ African Americans and other nonwhites may experience exclusion and discriminatory harm in their dealings with institutions, organizations, and even individuals, without white individuals intending them harm on the 
grounds of race. Poverty and lack of education, which is more prevalent in nonwhite than white communities, may be the result of intergenerational disadvantage that persists without ongoing ill will, bad intentions, or overt racist action on the part of privileged individuals. It is now broadly understood that disadvantage associated with race can persist, and even occur anew, in the absence of racists. However, the Katrina episode, together with the history of institutionalized racism in the United States, suggests a more intense version of institutional racism, in a very disturbing equation:

\section{Prior disadvantage + disaster $=$ institutional genocide .}

Indeed, the rage, frustration, and grief on the part of Katrina's victims and many serious onlookers exceeds a reaction to the statistics of the disaster itself. It suggests a fear and horror at the specter of a more general tragedy. The tragedy in this case goes beyond the vulnerability of the poor to disasters, or the now indisputably exposed facts of prior institutional racism. Of course the poor, especially the black poor, are vulnerable. But in normal times, their exclusion from many of the goods of white middle-class life occurs over long periods of time. Institutionalized racism is a pervasive but often subtle social problem, a condition. However, when just one aspect of institutionalized racism, namely segregated housing, is combined with disaster in a context of ongoing racial aversion and dismissal of suffering, it becomes more likely for large numbers to perish at once. When a segregated community is beset with a disaster, there are no opportunities for individuals to avoid dehumanizing identities and neglectful treatment by those who perceive the whole group under negative stereotypes. There is no time or space for individuals to escape. The net result looks like a very horrible new thing: institutionalized genocide. Something very like Katrina could happen again, and it could be bigger.

In normal life, many of the poor are able to 'pass' as not poor because they share the same mass culture with the rich and middle class. They watch the same television shows, eat the same food, aspire to the same luxury items, worship the same deities. As Jerry Springer has observed, the main difference between the people living on Park Avenue and in Beverly Hills and those who basked in the five minutes of fame he provided was money. It has been claimed that poverty is relative, meaning that the poor in America are economically better off than the poor in many other countries, particularly in the "third world." But the other side of that relativity is the gap in economic and resources between rich and poor in a country that is, for the most part, rich. Where extreme American poverty is comparable to living conditions in some third world countries, it turns out to be "relatively" worse, because of the size of that gap between our own 
rich and poor. This relegates the American poor to a kind of fourth world. Add black race, and its associated stereotypes and lack of opportunity, and we have a "fifth world." Now add disaster to black American poverty and the result is the aftermath of Hurricane Katrina, a "sixth world," its own circle of hell.

\section{Conspiracy Theory}

Suppose that "institutional genocide" and "the sixth world" were intended by ruling elites and others in positions to benefit from getting rid of specified groups of the poor? Suppose, also, that instead of white supremacy, or something like it, that the guiding ideology were economic, and the leading vice were not racism ${ }^{21}$ but greed, greed of the sort that holds ten billion dollars to be ten times as good as one billion dollars. Greed like that-motivating not Marvel comic villains, but real people who enjoy the support of government power-may already be a dominant factor in contemporary disaster as well as war. With this in mind, it is then a small step to imagine that the greedy villains welcomeif they do not directly cause-disaster, as well as war. This brings us to the threshold of conspiracy theory. Conspiracy theorists generate the most cynical analyses of events like Hurricane Katrina and the most depressing prognoses for the future. Worth consideration in this regard is Naomi Klein's 2007 book, The Shock Doctrine: The Rise of Disaster Capitalism. ${ }^{22}$

Klein claims to explain the global turn to a free market economy, which began during the last quarter of the twentieth century. Her thesis is that the growing power of international corporations and the decline of both socialism and paternalistic or welfare government were the result not of popular preference but of great coercion. The coercers, according to Klein, were the University of Chicago economist Milton Friedman's protegés and their associates. Milton taught his students, some of whom went on to influential careers in government, the absolute value of "free markets" to regulate human society. Although his ideas were not popular until after President Ronald Reagan assumed office, Milton and his followers were willing to wait until the right opportunities to dismantle welfare states presented themselves.

According to Klein, the Miltonians believed that when people are in a state of shock after an abrupt disruption of their normal lives, as from a military attack, a terrorist attack, or a natural disaster, they would offer less resistance to those neoconservative or neoliberal economic changes necessary to restore free markets. The term "shock," in addition to being the psychic side of disruptive events, also literally refers to clinical uses of electroshock therapy for mental patients, covert CIA-backed research into extreme applications of such therapy, and torture. When people are sufficiently shocked in any of the relevant ways, 
their minds are open and blank, and they can be reeducated or "reprogrammed." Klein claims that masses of shock victims have been coerced in exactly this way.

Here are some of Klein's international political examples. In the 1950s, Friedman advised the Chilean dictator Augusto Pinochet on implementing tax cuts, free trade, and reductions in social services, and he was also influential in Argentina's imposition of free market reforms that were accompanied by the "disappearance" of 30,000 leftists. In 1982, British Prime Minister Margaret Thatcher, a close correspondent of Friedman's, turned her low approval ratings around, after victory in the Falkland Islands. The excitement generated by patriotic celebration of the military victory allowed Thatcher to crush striking coal miners in the United Kingdom and instigate broad privatization of other utilities, as well as encourage rampant corporate capitalism. In 1989, the shock of the Tiananmen Square massacre was used by the Communist government to shift the entire economic basis of China to that of an export-based economy. In 1993, Boris Yeltsin, the first President of the Russian Federation, sent tanks to burn parliament buildings and lock up opposition leaders, creating a mass shock that cleared the way for his program of privatization and oligarchy.

When the World Trade Center was destroyed on 9/11, the White House contained many Friedman disciples, including Milton's close friend, Secretary of Defense Donald Rumsfeld. Klein claims that the goal of this cohort was to conduct the "Global War on Terror" by using private companies, which would lead to a privatization of government itself. Their program continued into the Iraq war, when between 2003 and 2006, the number of contracts for security functions increased from 3,512, to $115,000 .^{23}$

As Klein interprets it, the project of privatization has extended into "disaster capitalism." In Sri Lanka, after the 2004 Tsunami, the poor who lived along the coast and got their living from fishing were barred from returning home, and the government sold their land to luxury resort entrepreneurs. Klein reports that in the summer of 2004, FEMA rejected the State of Louisiana's request for funding of a contingency plan for a major hurricane. Instead, FEMA awarded a contract to a private firm, Innovative Emergency Management, to develop a hurricane disaster plan for Southeast Louisiana and New Orleans. At the cost of $\$ 1$ million, detailed and sensible plans for evacuation, water delivery, and instant trailer parks were submitted, but FEMA never acted upon them, due to a shortage of funds. Two weeks after Katrina hit, the Heritage Foundation hosted a meeting with Republican lawmakers and they developed thirtytwo ideas for "Hurricane Relief," including suspension of prevailing wage laws and vouchers for charter schools. Companies employed in Iraq, such as Halliburton, Blackwater, Parsons, 
Fluor, Shaw, Bechtel, and CH2M Hill, all received lucrative contracts for reconstruction services.

In addition, there were apparently many "indirect costs" in the privatization of Katrina. Klein provides the following examples. Kenyon, a division of the funeral conglomerate, Service Corporation International, had the contract to remove dead bodies at $\$ 12,500$ each; although Kenyon worked slowly (with results visible to the entire world), local morticians and volunteers were barred from helping. Shaw charged FEMA $\$ 175$ a square foot to install blue tarps, provided by the government, on damaged roofs, but the workers received $\$ 2$ a square foot. (The overall reconstruction workforce was at least one-quarter illegal Hispanic immigrants.) Lighthouse Disaster Relief, the company paid $\$ 5.2$ million by FEMA to construct a base camp for emergency workers in St. Bernard Parish, never completed this project, and was in fact a religious group, with prior experience only in building youth camps. ${ }^{24}$ Klein suggests that these abuses are related to a type of corruption whereby large corporations, after extensive lobbying and hefty campaign contributions, get contracts from the U.S. government, which they are not obligated to honestly fulfill. She writes:

According to The New York Times, "the top service contractors have spent nearly $\$ 300$ million since 2000 on lobbying and have donated $\$ 23$ million to political campaigns." The Bush administration, in turn, increased the amount spent on contractors by roughly $\$ 200$ billion between 2000 and $2006 .^{25}$

The biggest problem with Klein's account of contemporary disaster is its Manichaeanism. The reader is invited to reason from seemingly independent incidents and structures to a malevolent whole, which in turn gives meaning to its components. The result is a totally bleak picture of contemporary life, without direct evidence that there is a hidden, conspiratorial group that is able to plan contemporary disasters, for the sole overriding purpose of slaking its own greed. For instance, it is unlikely that all of the 115,000 security related government contracts were executed in fraudulent ways. Some unprincipled and greedy agents do have great power, and they on occasion have opportunities to cooperate in ways that harm large numbers. But it is a huge leap beyond available evidence to hold such groups responsible for all recent disasters. They may indeed begin wars, but others have to carry them out through their own efforts-or refuse to do so. And they may profit from natural catastrophes, but there is no evidence that they can create those catastrophes or that they are the only interests represented in responses to them. Capitalism, consumerism, the depletion and destruction of natural resources, oppression, and the inheritance of social disadvantage are all part of contemporary reality, 
but so is cooperation, productivity, conservation, liberation, and opportunity.

The construction and entertainment of conspiracy theories exhausts civic energy in outrage, so that autonomous agents are distracted from their own empowerment and plans for action. Utopias envisioned as an alternative to the source of outrage can induce a paralysis of the will to work for small change, because those utopias are so clearly unattainable. ${ }^{26}$ As Klein herself notes in the conclusion to The Shock Doctrine, there have already been political reversals of many of the policies she attributes to Friedman in Latin American and Europe, once initial 'shock' has worn off and people who have seen where their interests lie, have begun to organize for change. ${ }^{27}$ Such efforts and achievements could not have occurred if disaster capitalism and politics were always the monolithic system Klein implies.

\section{Disaster Activism}

The poor, as a mass, are not the same as the poor as individuals or the poor in small groups or neighborhoods. I have argued that there is not necessarily "strength in numbers," in terms of what will be done to people, or withheld from them. But obviously, two or six can accomplish more than one, on the level of individuals. Perhaps we can assume that there is strength in numbers, if we are talking about not mere numbers that amount to a stereotyped aggregate that is objectified by others, but the addition of persons. As people, "the poor" are not intrinsically helpless, and what happened in New Orleans need not be repeated, even if there is no change in government policy. Any small group can prepare for disaster by dividing labor, learning about evacuation routes, storing food, water, and extra clothing, as well as thinking about what they would do and what their normal obligations to care for themselves and others require them to do in a disaster. Collecting rainwater, basic first aid, and light search and rescue are examples of survival skills now within the reach of all U.S. residents. Every community in the United States now has some form of workplace, school, government, civic, volunteer, or do-it-yourself type of disaster preparation resource. FEMA and the Red Cross have instructions and information, including lists of necessary supplies, online.

Everybody who has dependents, whether professionally or personally, can begin to figure out what their needs would be in a disaster. People need to assess their disaster-related skills, assets, and liabilities and think about what they would do in unwanted but predicted contingencies, before they happen. Given what is already broadly known about the gaps in public and government disaster preparation and response, this is now a moral responsibility for individuals. Every disaster has had its compassionate and tireless volunteers. Ideally, every capable 
person would have some skill or resource qualifying them to help others, not solely for altruistic reasons, but because those who are prepared to help others are less likely to become helpless victims themselves.

\section{Capitalism and Disaster}

The issue is not whether private industry or government best provides vital goods and services, including disaster relief, but whether those goods and services are the best possible, given available resources, and what power the end user or consumer has. What we don't need, in order to prepare for disaster (although some might like it and the shift may or may not have merits on other grounds), is a fundamental change away from capitalism, or even global corporate capitalism. The major problem is not "privatization of government services," because the abuses documented by Naomi Klein and others are not due to that alone.

If government services for the military and disaster relief had in reality been privatized according to core capitalistic principles, and not merely baptized (by both supporters and critics) with the name, it could have happened in two ways. Either the government awarded contracts to the best companies, according to public criteria for their capabilities, or the government provided the end consuming units with vouchers to purchase what they needed from competing sources. Neither happened; instead, contracts in Iraq and New Orleans were awarded to private companies, sometimes in the absence of competitive bids and without public disclosure of criteria. In the absence of vouchers, end consumers, whether disaster victims or occupied Iraqis and relevant military purchasers, had no ability to choose among competing goods and service purveyors.

Let's assume that the tax money making up the federal budget is constant at any given time. Whether individual or institutional consuming and using units are given goods and services in kind, or vouchers (from tax money) to buy them, makes no difference to that budget. Charter schools and vouchers for them, where the schools are run by different, competing, private companies that pay the salaries of teachers, is an example of the privatization of education. But if only one company, paid by the government, furnishes education, funerary services, or roof repair, freely, or in exchange for vouchers, ${ }^{28}$ that is not "privatization" or even "monopoly capitalism." Insofar as end consumers have no choice and there has been no competition for contracts, it is a government-protected monopoly. This is ironic in light of Friedman-inspired aims to "privatize government." Instead of getting out of the picture, government has become more powerful by conferring its patronage without public disclosure of the merits of its chosen suppliers. 
It is a contingent matter whether certain goods and services can best be provided, at any given time and place, by government employees or those paid by private firms. For example, in some societies, public education dispenses propaganda, public food is inadequate and not nutritious, and public healthcare does not meet basic medical needs. In other societies, all of these failures attend private sales of education, food, and healthcare. To call the recent no-bid/no-choice abuses of our representational system "privatization," "outsourcing," or "global corporate capitalism," and assume those terms diagnose important problems, is to avoid the importance of standards for vital goods and services and overlook the democratic value of consumer autonomy. In a democratic society, it should not be presumed that those governed are passive in the hands of a kind or mean government. The real focus should be on the activity of those governed: The People.

\section{Spike Lee's View of the Disadvantaged after Katrina}

In principle, disaster is an equal opportunity event. A storm does not choose its victims. But, thus far, and not only in the United States, typical civilian disaster victims are already socially, economically, and politically disadvantaged. If this were always to be the case, for every foreseeable disaster, it would merit a completely socially constructivist approach to civilian disaster. "Civilian disaster" would mean "sudden misfortune in loss of life, well-being, and property that befalls a group or area of society that is already disadvantaged compared to other groups and areas." To an extent, this approach is assumed in some liberal representations of contemporary disaster, for example in Spike Lee's When the Levees Broke: A Requiem in Four Acts (2006), which bears the additional subtitle, "An American Tragedy."

Lee's documentary depicts the historical disadvantage of the African American victims of Hurricane Katrina. Shots of grieving over personal and material losses, references to the history of slavery, dramatic vignettes of interviewees' strong sense of place and home, and the jazz soundtracks throughout: all of these convey a distinctive black culture, with a rich background. Most of the displaced New Orleans residents were working people and homeowners, but once displaced they had few or no material resources. Part of the recovery efforts in New Orleans resulted in the employment of Hispanic migrant workers to rebuild the city, instead of unemployed black people. As Lee's subjects complain about this economic "slight" and those who are making money by seizing the land and dwellings of the dispersed, a familiar historical theme, reminiscent of slavery, and the general exploitation and dispersal of black people, is evoked. Lee sets this bleak tone early on with his replay of media footage 
of Konye West, saying “President Bush doesn't care about black people."

No whites in Lee's film appear as subjects expressing racist views. Barbara Bush's comment, that the Katrina refugees in the Houston Astrodome benefited from the storm, was bitterly denounced by several of Lee's subjects, but she herself is not presented directly. Thus, Lee's documentary represents the effects of white institutional racism, as his interviewees cope with a de facto racist catastrophe that has unfolded in the absence of racists. Again, well before Katrina, African Americans had already been excluded and discriminated against on economic or cultural grounds, without race per se ever being an explicit issue. ${ }^{29}$

Still, the disaster depicted is not wholly free of classic, intentional racism. A black interviewee describes being shot by whites using racist language against him and his cousin. Experiences of racism as direct hatred are expressed by black New Orleans residents who report having heard explosions when Katrina hit. Several of Lee's interviewees believe that the levees were bombed to spare white neighborhoods at the expense of black, something known to have occurred during the Great Flood of 1927. One 2005 New Orleans hurricane victim, who has been relocated to New York City, says she would not return home so that they could "finish me off." Black survivors recalling the first days after the storm recount incidents of helicopters passing them overhead, despite their desperate pleas and signs for help.

Unfolding from the storm warnings, to footage of storm destruction, to rescue and response efforts, to attempts at reconstruction and recovery, the four acts of When the Levees Broke tell a Big Story of American civilization from an African American perspective. In evoking the historical as well as contemporary disaster-based effects of racism, When the Levees Broke develops as a seemingly natural indictment of the Army Corp of Engineers, corrupt state and city government, and President George W. Bush. It is repeatedly made clear that the response to the hurricane and delay and negligence in recovery efforts constituted the disaster, which was merely precipitated by the storm. A local journalist claims that it was not the hurricane that caused the devastation, but poorly engineered levees that could not withstand even a Category 1 or 2 surge from Lake Pontchartrain.

\section{A Wider View}

While "shock doctrine" types of conspiracy or near-conspiracy theories and the near-paranoia expressed by Spike Lee's subjects yield valuable insights, they fall short of literal truths. Klein neither suggests nor establishes a full-blown behind-thescenes conspiracy. ${ }^{30}$ Her account proceeds "as if" government 
leaders have systematically attempted to implement a program for developing free markets, which was first proposed by Milton Friedman. Similarly, Lee's subjects do not engage in welldeveloped "theories" about the causes of their plight; their assessments of their situation proceed "as if" top government leaders "did not like black people." The valuable insights in both cases point to failures in both the transparency and effectiveness of government entities, which in a democratic society with egalitarian ideals, it must be assumed can be improved.

Moreover, on the issue of race and racism, we should note that racism against poor African Americans is not the whole story about what went wrong, or what was right, in the response to Katrina. Spike Lee made no attempt at a thorough description of the storm dynamics of Hurricane Katrina, the problems with the models of hurricanes used by engineers, or the complexity of the weather conditions in New Orleans when Katrina hit. ${ }^{31}$ Some disaster officials now believe that the response effort in New Orleans was successful in two ways: the U.S. Coast Guard rescued over 33,$000 ;{ }^{32}$ the Houston Astrodome, dubbed "Reliant City," provided temporary shelter and living supplies for 65,000 evacuees for twenty-one days, until it had to be evacuated because of Hurricane Rita. ${ }^{33}$

African Americans were not the only victims of Katrina ${ }^{34}$ In addition to the 830 African American deaths, there were 553 whites who died, and 444 for whom no race was specified. Although two white sisters, one emboldened by drinking beer, make stinging critical comments against government, little is said or shown in the documentary about the vulnerability of the elderly, as a distinct group, or the plight of the handicapped. For instance, Benilda Caixeta was a wheelchair-bound, middle-class, Hispanic woman who slowly drowned to death in her apartment, after repeated assurances from contacts all over the country that she would be rescued. ${ }^{35}$

The conclusion to be drawn here is twofold. First, compassion for neglected and abused disaster victims and outrage at such injustice is well justified. But second, even in Katrina, prior disadvantage included at least disability and age, as well as race and class. Reasoning more broadly from Katrina, we can say that disaster preparation and response should be needsbased. This is because not all socially disadvantaged groups will necessarily suffer equal disadvantages in disasters, and any identity-based special preparations will likely be at least as contentious as Affirmative Action in normal times. Needs, whether they are for food, water, shelter, transportation for evacuation, or personal mobility assistance, translate directly into preparation and resource deployment, in egalitarian ways. For a more trivial example, in the present mood of air travel, if most passengers heard that special arrangements were in place for handicapped travelers, which were being financed by increases 
in the prices of all tickets, many would object. And more would protest if fare increases included funds for hiring additional personnel who could translate for non-English speaking passengers. But if a certain number of wheelchairs are said to be needed, and more service personnel were said to be needed, the reaction would probably be more generous.

\section{Notes}

This paper appears in Naomi Zack, Ethics for Disaster (Rowman and Littlefield, 2009), chapter 6, "The Disadvantaged and Disaster: Hurricane Katrina."

1 Patrick Creed and Rick Newman, Firefight: Inside the Battle to Save the Pentagon on 9/11 (New York: Ballantine Books, 2008), 330.

2 (C) 1964, renewed in 1992 by Special Rider Music.

3 For an account of the rest of Zantzinger's life and how Hattie Carroll's relatives remember her, see Ian Frazier, "Legacy of a Lonesome Death," Mother Jones, November/December 2004 Issue, at http:// www.motherjones.com/commentary/slant/2004/11/10_200.html

${ }^{4}$ press_releases/president_bush_signs_pets_Act.html

5 One-third (200 of 600$)$ of the border patrol personnel were rassigned to help fight the fires (see www.msnbc.msn.com/id/21437752/). However there were both news stories and television reports of illegal aliens who were kept working in smoke-filled conditions in tomato fields; a Mexican family of twelve, accused of looting in San Diego's Qualcomm stadium was summarily deported to Tijuana; many poor communities, including Native American reservations, were not evacuated and their inhabitants were neglected by official sources of aid, including the Red Cross. Documented by Justin Akers Cacón, Professor of Chicano Studies at UC San Diego, in "Divided by Fire: Two San Diegos Emerge from the Flames." Accessed October 30, 2007, from www.socialistworker.org/2007-2/651/651_06_Divided.shtml and www.dissidentvoice.org/author/JustinAkers/

6 news.yahoo.com/s/ap/20071115/ap_on_go_pr_wh/airline_delays

7 www.helpjet.us

8 Naomi Klein, The Shock Doctrine: The Rise of Disaster Capitalism (New York: Metropolitan Books, 2007), 415-16. Help jet's website is www.helpjet.us

9 This account relies on The White House, "The Federal Response to Hurricane Katrina: Lessons Learned 5-9" (2006), reprinted in Daniel A. Farber and Jim Chen, Disasters and the Law: Katrina and Beyond (New York: Aspen Publishers, 2006), 2-5. This report was written in February 2006, and at that time, the figure for the number of evacuees who had not returned was 500,000. Writers in 2007 put it at about 300,000 . See, e.g., Julian Bond, "In Katrina's Wake," The Journal of Race and Policy, ed. Michael L. Clemons, Vol. 3, Spring/ Summer 2007, Special Issue, In Katrina's Wake: Racial Implications of the New Orleans Disaster (Norfolk, VA: Institute for the Study of Race and Ethnicity at Old Dominion University), 27.

${ }^{10}$ For this part of my account, I have mainly relied on Julian Bond, "In Katrina's Wake," 15-22, and Donald A. Saucier, Sara J. Smith, and Jessica L. McManus, "The Possible Role of Discrimination in the Rescue Response after Hurricane Katrina," in The Journal of Race and 
Policy, 113-14.

${ }_{11}$ Martell L. Teasley, "Organizational Cultural Competence and Disaster Relief Participation," in The Journal of Race and Policy, 10212.

${ }^{12}$ Bond, "In Katrina's Wake," 28, 29, and M. Davis, "Who is Killing New Orleans?" The Nation, April 10, 2006, and The Center for Social Inclusion, "The Race to Rebuild: The Color of Opportunity and the Future of New Orleans," August 2006, http://www.centerforsocial inclusion.org/publications.html

${ }^{13}$ Lakshmi Fjord, "Disasters, Race and Disability: [Un] Seen Through the Political Lens on Katrina," in The Journal of Race and Policy, 46-65, House report cited on pp. 46-47 as U.S. House of Representative, A Failure of Initiative: Final Report of the Select Bipartisan Committee to Investigate the Preparation for and Resonse to Hurricane Katrina, 109th Congress, 2nd Session, Report 000-000, February 15, 2006, p. 223.

${ }^{14}$ Cited, "Disasters, Race and Disability," 52.

${ }^{15}$ Ibid.

${ }^{16}$ Bond, “In Katrina's Wake," 18.

${ }^{17}$ Ibid., 19, quoted from The White House, Office of the Press Secretary, 2005.

${ }^{18}$ Ibid., 15, quoted from B. Ransby, "Katrina, Black Women, and the Deadly Discourse on Black Poverty in America," DuBois Review 3, no. 1 (Spring 2006): 217.

${ }^{19}$ Cf. Fjord, "Disasters, Race and Disability," 46-65.

${ }^{20}$ See Naomi Zack, "Race and Racial Discrimination," in Oxford Handbook of Practical Ethics, ed Hugh Lafollette (Oxford University Press, 2002), 245-71.

${ }^{21}$ For discussion of how racism is a vice, see Zack, "Race and Racial Discrimination," 245-71.

${ }^{22}$ Klein, The Shock Doctrine.

${ }^{23}$ Ibid., 3-12.

${ }^{24}$ Ibid., 409-12. Many of Klein's sources are articles in the New York Times, which is to say that the arrangements she reports have hardly been a secret.

${ }_{25}$ Ibid., 412.

${ }^{26}$ Indeed, the "consumption" of conspiracy theories, as well as their construction, which have flourished since $9 / 11$ seem to be a substitute for realistic political engagement in some cases. See Mark Fenster, Conspiracy Theories: Secrecy and Power in American Culture (Minneapolis: University of Minnesota Press, 2008), esp. 279-91.

${ }^{27}$ Klein, The Shock Doctrine, 424-66.

${ }^{28}$ See Klein, The Shock Doctrine, 410-12.

${ }^{29}$ See Naomi Zack, Thinking About Race (Belmont, CA: Thomson Wadsworth, 2006), ch. 5; Glenn C. Loury, The Anatomy of Racial Inequality (Cambridge, MA: Harvard University Press, 2002).

${ }^{30}$ Such accounts, complete with secret powerful groups, who form the real government in controlling mass events are not wanting at this time. For instance, there is the post-9/11 Truth Movement, as documented by Fenster in Conspiracy Theories (197-278). And of course there are the theories themselves, for example, the Internet video Zeitgeist: Addendum and Daniel Estulin's The Bilderberg Group (Walterville, OR: Trineday, LLC, 2007). 
${ }^{31}$ See John Schwartz, "An Autopsy of Katrina: Four Storms, Not Just One," New York Times, May 30, 2008, available at nytimes.com

${ }^{32}$ See "Coast Guard: Observations on the Preparation, Response, and Recovery Missions Related to Hurricane Katrina," GAO-06-903, www.gao.gov/docsearch/abstract.php?rptno=GAO-06-903

${ }^{33}$ At the 2006 National CERT conference in Los Angeles, May 1317 , government officials presented films of the response to Hurricane Katrina that depicted their own success and heroism. CERT, or Citizens Emergency Response Teams, is a national organization that offers standardized first response training to volunteers in local communities.

${ }^{34}$ In fact the statistics on deceased show substantial deaths in racial categories other than black, according to the list, below, maintained by Columbia University at www.katrinalist.columbia.edu

\begin{tabular}{lr} 
Breakdown of Race & \\
\hline African American & 830 \\
Caucasian & 553 \\
Hispanic & 36 \\
Native American & 6 \\
Asian/Pacific Islander & 14 \\
Other & 0 \\
No race specified & 444
\end{tabular}

${ }^{35}$ June Isaacson Kailes, "Serving and Protecting All by Applying Lessons Learned-Improving Access to Disaster Services for People with Disabilities and Seniors," www.jik.com/11-28-05\%20CHHS_Draft_ Report\%20V1-3aRestricted.doc. See also, www.benildacaixeta.com. Names and demographics of all 1890 victims can be found at www. katrinalist.columbia.edu 